\title{
Nutritional Value of Soybean Meal from Various Geographic Origin and Effect of Their Dietary Supplementation on Performance of Broilers
}

\author{
Bo Keun Lee*, Jae Young Kim*, Ji Sook Kim*, Sun Jong You*, Byoung Ki An*, Eun Jib Kim** \\ and Chang Won Kang* \\ Animal Resources Research Center, College of Animal Bioscience and Technology, Konkuk University*, \\ Division of Animal Care, Cheonan Yonam College**
}

\author{
원산지가 다른 대두박의 영양적 가치평가와 육계의 생산성에 미치는 영향 \\ 이보근* · 김재영* • 김지숙* • 유선종* • 안병기* · 김은집** · 강창원* \\ 건국대학교 동물생명과학대학 동물자원연구센터*, 천안연암대학 동물복지계열**
}

\begin{abstract}
요 약
본 연구는 일반대두박인 아르헨티나, 인도 및 한국산 그리고 탈피대두박인 미국산 대두박의 육계 사료원료로서의 영양적 품질을 평가하기 위한 목적으로 수행되었다. 대두박의 영양적 가치평가를 위해 일반성분, 아미노산 함량, TME, TMEn, 아 미노산 이용률, urease 활성도 및 $\mathrm{KOH}$ 용해도를 측정하였고, 육계의 생산성 평가를 위해 20일령의 육용종 수평아리 (Ross) 400 수에게 옥수수 - 대두박을 기초로 각 처리구 별로 원산지가 다른 대두박을 이용한 실험사료를 15 일간 급여하였으며, 4 처 리 4반복(반복당 25 수)으로 완전 임의 배치하여 사양실험을 실시하였다. 대두박의 일반성분과 아미노산의 함량을 조사한 결과 조단백질 함량은 $45.43 \%$ (아르헨티나산)에서 $48.47 \%$ (미국산)의 범위였고, 조지방 함량은 $1.11 \%$ (인도산)에서 $1.96 \%$ (아 르헨티나산)의 범위였다. 조회분 함량은 $5.89 \%$ (아르헨티나산)에서 $7.18 \%$ (인도산)의 범위였고, 조섬유 함량은 $3.48 \%$ (미국산) 에서 $7.12 \%$ (인도산)의 범위였다. 아미노산의 함량은 조단백질 함량과 비례하여 미국산이 가장 높았으며, 대부분의 아미노 산 함량에서 인도산과 아르헨티나산이 유의하게 낮은 수치를 보였다. 에너지 함량 즉 TME와 TMEn 값은 미국산이 각각 $3245.4 \mathrm{kcal} / \mathrm{kg}$ 및 $3228.9 \mathrm{kcal} / \mathrm{kg}$ 으로 가장 높았으며, 한국산, 아르헨티나산, 인도산의 순으로 낮았으나 유의한 차이는 아니었 다. 아미노산 이용률은 평균적으로 유의한 차이는 아니었으나, 미국산이 가장 높았고 한국산, 아르헨티나산, 인도산의 순으 로 낮았다. Urease 활성도는 대두박 간에 유의한 차이가 없었고, $\mathrm{KOH}$ 용해도의 결과를 보면 아르헨티나산의 KOH 용해도 가 유의하게 낮은 수치를 보였으나 모든 대두박이 허용치를 벗어나지 않아 모두 적절한 열처리를 한 대두박의 결과를 나 타냈다. 종료체중, 증체량 및 사료섭취량 모두 유의한 차이가 없었으나 사료요구율은 미국산이 유의하게 낮은 결과를 보였 다 (P<0.05). 도체특성 및 혈 중 총 콜레스테롤 농도는 모두 통계적으로 유의한 차이를 보이지 않았다.
\end{abstract}

(Key words: Dietary supplementation, Soybean meal, Broiler chickens)

\section{I . INTRODUCTION}

Soybean meal (SBM) is obtained after extracting oil from soybean. Currently, SBM is the most valuable feed ingredient for livestock due to its higher crude protein, better amino acid profile and lower cost when compared with other oil meals (Aburto et al., 1998; Batal and Parsons, 2003). The lysine content of SBM is relatively high but methionine and cystine contents are relatively low compared to those found in other plant meals (Eggum and Beames, 1983; McNaughton et al., 1981).

Most of the feed millers analyze only proximate chemical composition (moisture, crude protein, crude fat, crude fiber, and crude ash), calcium and phosphorus for the formulation of mixed feeds. They use values provided by ARC and NRC for contents of energy and amino acids regardless of ingredient quality. This may result in erroneous formulation in terms of nutritional quality because those values do not reflect huge variation in nutritional quality and economic returns of feedstuffs. For example, pepsin digestibility measurements of 9 samples of local fishmeal in Korea revealed high variation ranging from $35.4 \%$ to $65.8 \%$ (Kang, 1993) indicating availability of amino acids varied widely. Nutritional quality of SBM used in Korea also varied widely

Corresponding author: Dr. C. W. Kang, College of Animal Bioscience and Technology, Konkuk University, 1 Hwayang-dong, Gwangjin-gu, Seoul 143-701, Korea. E-mail: kkucwkang@empal.com 
(Joo et al. 1994).

Even though various vegetable protein meals contain similar chemical compositions, their values for ME (metabolizable energy) and/or amino acid availability can be quite different. Therefore, mixed feeds should be formulated based on ME and amino acid availability rather than proximate analysis of the vegetable protein meals. However, it is difficult to get ME and/or amino acid availability prior to formulating feeds because determination of ME and amino acid availability for every shipment of vegetable protein meals are timeconsuming and expensive.

SBM as well as most of the plant protein sources contains anti-nutritional factors (ANF) such as trypsin inhibitor and saponins which may exert unfavorable influences on feed quality, especially for non-ruminant animals. However, most of them are easily destroyed by heat treatment and thus SBM must be heat-processed to satisfy nutritional quality for poultry feed. While a certain amount of heat is required to deactivate ANF, overheating of SBM may be detrimental to its nutritional value due to the Maillard reaction (Whittle and Araba, 1992). Since SBM needs to be properly heat-treated, some criteria are needed to assess the degree of heat treatment. Araba and Dale (1990) used $0.2 \% \mathrm{KOH}$ solution for determining of protein solubility and found high correlation between protein solubility and growth of chickens. Useful methods for determining quality of underheated SBM involve determination of urease and trypsin inhibitor activities (Wright, 1981). The method of Caskey and Knapp (1944) is most widely used for the determination of urease activity.

The efficient evaluation of feed ingredients is important in order to provide the accurate amount of necessary nutrients and to predict performance of livestock (Kang, 1993). The nutritional quality of SBM differs mainly due to differences in genetic varieties, environmental factors and processing conditions. It is important to evaluate whether variations in the quality of SBM occur among geographic regions. The purpose of this study was to compare the nutritional quality of SBM from leading SBM producing countries by in vitro assay, bioassay and subsequent feeding trial.

\section{MATERIALS AND METHODS}

\section{Analytical and availability evaluation of SBMs}

Samples of non-dehulled SBM used in this study were originated from Argentina (ARG), India (IND) and Korea (KOR), while samples of dehulled SBM originated from USA. SBM from different geographic origins were first analyzed for DM, CP, ether extract, and crude fiber by the methods outlined by the AOAC (2000). The amino acid contents of SBM from different origins were determined by amino acid analyzer (Amino Acid Analyzer 430, SYKAM $\mathrm{GmbH}$, Germany). True metabolizable energy (TME) and nitrogen corrected true metabolizable energy (TMEn) were assessed by using Hy-Line Variety Brown roosters according to the force-feeding method as described by Sibbald (1979) with some modifications. Following a 24-h of feed withdrawal, fifteen roosters (Hy-line Variety Brown, 62 weeks of age) were force-fed $30 \mathrm{~g}$ SBM from different origins via crop intubation. Five additional roosters were deprived of feed for 24-h period and these roosters were used as control to obtain nitrogen corrected metabolic fecal and endogenous urinary losses. All the excreta were collected for 24-h, freeze dried to determine gross energy by the adiabatic oxygen bomb calorimeter (PARR 1261, PARR Instruments Co., Moline, IL 65265).

The amino acid digestibility was measured using the same procedures as for TMEn assay. The true amino acid availability (TAAA) values were determined and corrected for metabolic fecal and endogenous urinary amino acids as described by Likuski and Dorrell (1978).

Urease activity (UA) was measured by the phenol red indicator method proposed by Caskey and Knapp (1944), and $\mathrm{KOH}$ solubility according to the method proposed by Dale et al. (1987).

\section{Feeding trial}

Ross broiler chicks ( $\mathrm{n}=400,753.5-755.1 \mathrm{~g} / \mathrm{bird}, 20$ days of age) were randomly allotted to four treatments. Each treatment had four replicate pens with 25 birds in each pen. The birds were raised on deep litter temperature controlled house and were provided continuous lighting. The birds were fed one of the following four diets containing SBM from ARG, IND, KOR and USA for 15 days. The test diets containing SBM from different geographic origins were formulated to be equal in the contents of $\mathrm{CP}(20.00 \%)$, TMEn $(3,150 \mathrm{kcal} / \mathrm{kg})$, lysine $(1.00 \%)$ and sulfur containing amino acids $(0.72 \%)$. The nutrient specifications of the diets were met or exceeded the minimum requirement of NRC (1994). All the chicks were provided free access to feed and water. Feed intake and body weight of each group were recorded weekly.

At the end of experimental period, 10 chicks from each group were randomly selected. Sterile syringes were used to collect blood from wing vein of chicks and total cholesterol was measured. For serum, the blood samples were allowed 
Table 1. Formula and chemical composition of the experimental diets

\begin{tabular}{|c|c|c|c|c|}
\hline Ingredients $(\%)$ & ARG & IND & KOR & USA \\
\hline Soybean meal ${ }^{1)}$ & 27.50 & 27.50 & 27.50 & 27.50 \\
\hline Corn & 52.74 & 52.82 & 53.32 & 53.78 \\
\hline Wheat & 10.00 & 10.00 & 10.00 & 10.00 \\
\hline Corn gluten meal & 3.27 & 2.93 & 2.83 & 2.51 \\
\hline Tallow & 2.89 & 3.19 & 2.81 & 2.71 \\
\hline Dicalcium phosphate & 1.42 & 1.42 & 1.42 & 1.42 \\
\hline Limestone & 1.25 & 1.25 & 1.25 & 1.25 \\
\hline Choline-chloride $(50 \%)$ & 0.02 & 0.02 & 0.02 & 0.02 \\
\hline Salt & 0.29 & 0.29 & 0.29 & 0.29 \\
\hline Mineral $\operatorname{mix}^{2)}$ & 0.15 & 0.15 & 0.15 & 0.15 \\
\hline Vitamin $\operatorname{mix}^{3)}$ & 0.11 & 0.11 & 0.11 & 0.11 \\
\hline Lysine $(25 \%)$ & 0.19 & 0.15 & 0.13 & 0.09 \\
\hline Alimet $(88 \%)$ & 0.02 & 0.02 & 0.02 & 0.02 \\
\hline Antibiotics & 0.10 & 0.10 & 0.10 & 0.10 \\
\hline Anticoccidials & 0.05 & 0.05 & 0.05 & 0.05 \\
\hline Total & 100.00 & 100.00 & 100.00 & 100.00 \\
\hline Calculated value of bas & & & & \\
\hline Crude protein, \% & \multicolumn{4}{|c|}{20.00} \\
\hline $\mathrm{Ca}, \%$ & \multicolumn{4}{|c|}{0.90} \\
\hline Available $\mathrm{P}, \%$ & \multicolumn{4}{|c|}{0.35} \\
\hline Lysine, \% & \multicolumn{4}{|c|}{1.00} \\
\hline Met+Cys, \% & \multicolumn{4}{|c|}{0.72} \\
\hline Threonine, $\%$ & \multicolumn{4}{|c|}{0.74} \\
\hline $\mathrm{ME}, \mathrm{kcal} / \mathrm{kg}$ & \multicolumn{4}{|c|}{3,150} \\
\hline
\end{tabular}

1) Originated from Argentina (ARG), India (IND), Korea (KOR) and U.S.A. (USA).

2) Mineral mixture provided following nutrients per $\mathrm{kg}$ of diet: Fe, $96 \mathrm{mg} ; \mathrm{Zn}, 120 \mathrm{mg} ; \mathrm{Mn}, 144 \mathrm{mg} ; \mathrm{Cu}, 10 \mathrm{mg} ; \mathrm{I}, 2 \mathrm{mg} ; \mathrm{Se}, 0.36 \mathrm{mg}$; Co, $0.48 \mathrm{mg}$.

3) Vitamin mixture provided following nutrients per $\mathrm{kg}$ of diet: vitamin $\mathrm{A}, 21,000 \mathrm{IU}$; vitamin $\mathrm{D}_{3}, 4,500 \mathrm{IU}$; vitamin $\mathrm{E}$, $60.0 \mathrm{mg}$; vitamin $\mathrm{K}_{3}, 3.6 \mathrm{mg}$; vitamin $\mathrm{B}_{1}, 1.8 \mathrm{mg}$; vitamin $\mathrm{B}_{2}, 7.5 \mathrm{mg}$; vitamin $\mathrm{B}_{6}, 4.5 \mathrm{mg}$; vitamin $\mathrm{B}_{12}, 0.03 \mathrm{mg}$; niacin, $60.0 \mathrm{mg}$; pantothenic acid, $15.0 \mathrm{mg}$; folic acid, $0.75 \mathrm{mg}$; biotin, $0.1 \mathrm{mg}$.

to clot in polypropylene tubes for $2 \mathrm{~h}$ at room temperature. The tubes were centrifuged at $1,500 \mathrm{rpm}$ for $10 \mathrm{~min}$, and the supernatant was removed and stored at $-20^{\circ} \mathrm{C}$ until assayed. The concentration of total cholesterol in serum was measured according to the colorimetric method using cholesterol diagnostic kit (Total cholesterol kit, Asan Pharmaceutical, Seoul, Korea).

The data obtained was subjected to ANOVA using the GLM procedure of SAS (2002), and significant differences were determined using Duncan's multiple range test at the level of $\mathrm{p}<0.05$ (Duncan, 1955).

\section{RESULTS AND DISCUSSION}

Proximate composition and amino acid profiles of SBM from ARG, IND, KOR and USA are provided in Table 2. According to the chemical analysis, the contents of $\mathrm{CP}$ ranged from $45.43 \%$ (ARG) to $48.47 \%$ (USA) and those of crude fat from $1.11 \%$ (IND) to $1.96 \%(\mathrm{ARG})$. The contents of crude ash varied from $5.89 \%$ (ARG) to $7.18 \%$ (IND) and those of crude fiber varied widely from $3.48 \%$ (USA) to $7.12 \%$ (IND). The amino acid contents of SBM originating from KOR and USA were higher than SBM originating from ARG and IND. The contents of lysine varied from $2.79 \%$ (IND) to $3.09 \%$ (USA) and those of methionine from $0.56 \%$ (IND) to $0.65 \%$ (USA). The values are comparable with those of non-dehulled and dehulled SBM reported by NRC (1994). These results demonstrated differences in nutritive values between non-dehulled and dehulled SBM. Overall amino acid profiles of the SBM appeared very similar among the samples when they were expressed as percent of protein.

The values of TME and TMEn of SBM from ARG, IND, KOR and USA are provided in Table 3 . The values of TME 
Table 2. Chemical and amino acid composition of soybean meals ${ }^{1)}$

\begin{tabular}{|c|c|c|c|c|}
\hline \multirow{2}{*}{ Items } & \multicolumn{4}{|c|}{ Soybean meals } \\
\hline & ARG & IND & $\mathrm{KOR}$ & USA \\
\hline & \multicolumn{4}{|c|}{ 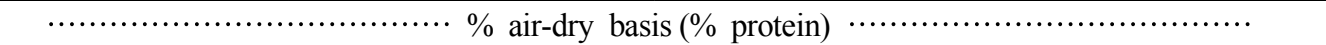 } \\
\hline Moisture & $11.30 \pm 0.03^{\mathrm{d}}$ & $11.49 \pm 0.01^{\mathrm{c}}$ & $12.71 \pm 0.00^{\mathrm{a}}$ & $12.04 \pm 0.03^{\mathrm{b}}$ \\
\hline Crude protein & $45.43 \pm 0.08^{\mathrm{c}}$ & $45.51 \pm 0.14^{\mathrm{c}}$ & $46.42 \pm 0.11^{\mathrm{b}}$ & $48.47 \pm 0.15^{\mathrm{a}}$ \\
\hline Crude fat & $1.96 \pm 0.03^{\mathrm{a}}$ & $1.11 \pm 0.02^{\mathrm{d}}$ & $1.55 \pm 0.02^{\mathrm{c}}$ & $1.64 \pm 0.02^{\mathrm{b}}$ \\
\hline Crude ash & $5.89 \pm 0.03^{\mathrm{d}}$ & $7.18 \pm 0.07^{\mathrm{a}}$ & $6.24 \pm 0.02^{\mathrm{b}}$ & $6.10 \pm 0.03^{\mathrm{c}}$ \\
\hline Crude fiber & $4.50 \pm 0.15^{\mathrm{b}}$ & $7.12 \pm 0.05^{\mathrm{a}}$ & $4.33 \pm 0.09^{\mathrm{b}}$ & $3.48 \pm 0.05^{\mathrm{c}}$ \\
\hline \multicolumn{5}{|l|}{ Amino acids } \\
\hline Aspartic acid & $5.15 \pm 0.01^{\mathrm{c}}(11.3)$ & $5.10 \pm 0.01^{\mathrm{c}}$ & $5.29 \pm 0.02^{\mathrm{b}}$ & $5.45 \pm 0.05^{\mathrm{a}}$ \\
\hline Threonine & $1.91 \pm 0.00^{\mathrm{c}}$ & $1.82 \pm 0.01^{\mathrm{d}}(4.0)$ & $1.95 \pm 0.01^{\mathrm{b}}$ & $1.99 \pm 0.02^{\mathrm{a}}$ \\
\hline Serine & $2.30 \pm 0.00^{\mathrm{b}}$ & $2.31 \pm 0.03^{\mathrm{b}}$ & $2.38 \pm 0.02^{\mathrm{a}}$ & $2.40 \pm 0.02^{\mathrm{a}}$ \\
\hline Glutamic acid & $8.54 \pm 0.02^{\mathrm{c}}$ & $8.50 \pm 0.01^{\mathrm{c}}(18.7)$ & $8.82 \pm 0.03^{b}$ & $9.12 \pm 0.08^{\mathrm{a}}$ \\
\hline Glycine & $1.96 \pm 0.01^{\mathrm{c}}$ & $1.92 \pm 0.01^{\mathrm{d}}(4.2)$ & $2.02 \pm 0.00^{\mathrm{b}}$ & $2.07 \pm 0.02^{\mathrm{a}}$ \\
\hline Alanine & $2.08 \pm 0.01^{\mathrm{b}}$ & $1.97 \pm 0.01^{\mathrm{c}}$ & $2.10 \pm 0.01^{\mathrm{b}}$ & $2.16 \pm 0.01^{\mathrm{a}}$ \\
\hline Valine & $2.12 \pm 0.02^{\mathrm{b}}$ & $1.94 \pm 0.08^{\mathrm{c}}$ & $2.11 \pm 0.03^{\mathrm{b}}$ & $2.27 \pm 0.03^{\mathrm{a}}$ \\
\hline Isoleucine & $1.89 \pm 0.02^{\mathrm{b}}$ & $1.74 \pm 0.08^{\mathrm{c}}$ & $1.89 \pm 0.02^{\mathrm{b}}$ & $2.04 \pm 0.03^{\mathrm{a}}$ \\
\hline Leucine & $3.52 \pm 0.02^{\mathrm{b}}(7.7)$ & $3.39 \pm 0.03^{\mathrm{c}}$ & $3.55 \pm 0.01^{\mathrm{b}}(7.6)$ & $3.68 \pm 0.04^{\mathrm{a}} \quad(7.6)$ \\
\hline Tyrosine & $1.61 \pm 0.01$ & $1.56 \pm 0.02$ & $1.60 \pm 0.02$ & $1.64 \pm 0.02$ \\
\hline Phenylalanine & $2.37 \pm 0.01^{\mathrm{b}}$ & $2.32 \pm 0.01^{\mathrm{c}}$ & $2.39 \pm 0.01^{\mathrm{b}}(5.1)$ & $2.47 \pm 0.03^{\mathrm{a}}$ \\
\hline Lysine & $2.83 \pm 0.01^{\mathrm{c}}$ & $2.79 \pm 0.03^{\mathrm{c}}$ & $2.97 \pm 0.01^{\mathrm{b}}$ & $3.09 \pm 0.03^{\mathrm{a}}$ \\
\hline Histidine & $1.11 \pm 0.00^{\mathrm{c}}$ & $1.10 \pm 0.01^{\mathrm{c}}$ & $1.16 \pm 0.00^{\mathrm{b}}$ & $1.20 \pm 0.01^{\mathrm{a}}$ \\
\hline Arginine & $3.16 \pm 0.02^{\mathrm{c}}$ & $3.19 \pm 0.01^{\mathrm{c}}(7.0)$ & $3.33 \pm 0.01^{\mathrm{b}}(7.2)$ & $3.50 \pm 0.03^{\mathrm{a}}$ \\
\hline Cystine & $0.57 \pm 0.00^{\mathrm{b}}$ & $0.58 \pm 0.00^{\mathrm{b}}$ & $0.68 \pm 0.00^{\mathrm{a}}$ & $0.68 \pm 0.00^{\mathrm{a}}$ \\
\hline Methionine & $0.58 \pm 0.01^{\mathrm{c}}$ & $0.56 \pm 0.00^{\mathrm{c}}$ & $0.63 \pm 0.00^{\mathrm{b}}$ & $0.65 \pm 0.00^{\mathrm{a}}$ \\
\hline
\end{tabular}

1) Originated from Argentina (ARG), India (IND), Korea (KOR) and U.S.A. (USA).

2) Values represent Mean \pm SE.

${ }^{\mathrm{a}-\mathrm{d}}$ values with different superscripts in a row were significantly differ $(\mathrm{P}<0.05)$.

Table 3. Energy values of soybean meals (dry matter basis) ${ }^{1,2)}$

\begin{tabular}{|c|c|c|c|c|}
\hline \multirow{2}{*}{ Items } & \multicolumn{4}{|c|}{ Soybean meals } \\
\hline & $\mathrm{ARG}$ & IND & KOR & USA \\
\hline & ㄹ................. & p..................... & & …............ \\
\hline TME & $3113.1 \pm 30.03$ & $3011.1 \pm 100.29$ & $3135.3 \pm 46.12$ & $3245.4 \pm 51.52$ \\
\hline TMEn & $3092.4 \pm 28.24$ & $2986.6 \pm 96.90$ & $3110.4 \pm 48.01$ & $3228.9 \pm 48.33$ \\
\hline
\end{tabular}

\footnotetext{
1) Originated from Argentina (ARG), India (IND), Korea (KOR) and U.S.A. (USA).

2) Values represent Mean \pm SE.
}

ranged from $3,011.1 \mathrm{kcal} / \mathrm{kg}$ (IND) to $3,245.4 \mathrm{kcal} / \mathrm{kg}$ (USA) and those of TMEn from $2,986.6 \mathrm{kcal} / \mathrm{kg}$ (IND) to $3,228.9$ (USA). These results are similar to the data reported by Joo et al. (1994) with TMEn values of $2,750 \mathrm{kcal} / \mathrm{kg}$ to 3,438 $\mathrm{kcal} / \mathrm{kg}$. Joo et al. (1994) reported that the values of TMEn were $3,384 \mathrm{kcal} / \mathrm{kg}$ for $\mathrm{ARG}, 2,750 \mathrm{kcal} / \mathrm{kg}$ and 3,075 $\mathrm{kcal} / \mathrm{kg}$ for IND, $3,350 \mathrm{kcal} / \mathrm{kg}$ for $\mathrm{KOR}$ and $3,438 \mathrm{kcal} / \mathrm{kg}$ and $3,104 \mathrm{kcal} / \mathrm{kg}$ for USA. But values of TME and TMEn reported in this study are much higher than those values for soybean meals reported by NRC (1994).

True amino acid availabilities (TAAA) of SBM from ARG, IND, KOR and USA are provided in Table 4. The averages of TAAA were $92.27 \%$ for USA, $92.19 \%$ for KOR, $91.98 \%$ for ARG and $91.61 \%$ for IND. The availability of lysine 
Table 4. True amino acid availability of soybean meals (dry matter basis) ${ }^{1), 2)}$

\begin{tabular}{|c|c|c|c|c|}
\hline \multirow{2}{*}{ Items } & \multicolumn{4}{|c|}{ Soybean meals } \\
\hline & ARG & IND & KOR & USA \\
\hline & & & & $\ldots \ldots \ldots$ \\
\hline Aspartic acid & $93.07 \pm 0.47$ & $92.62 \pm 1.01$ & $93.00 \pm 0.44$ & $92.89 \pm 0.04$ \\
\hline Threonine & $91.29 \pm 0.19$ & $90.86 \pm 1.50$ & $91.36 \pm 1.99$ & $90.95 \pm 0.52$ \\
\hline Serine & $92.26 \pm 0.89$ & $92.35 \pm 0.97$ & $92.17 \pm 1.36$ & $92.46 \pm 0.62$ \\
\hline Glutamic acid & $94.53 \pm 0.04$ & $94.32 \pm 0.62$ & $94.37 \pm 0.40$ & $94.71 \pm 0.12$ \\
\hline Alanine & $88.13 \pm 0.96$ & $88.04 \pm 2.88$ & $89.88 \pm 1.68$ & $88.98 \pm 0.68$ \\
\hline Valine & $90.39 \pm 0.68$ & $89.22 \pm 2.11$ & $91.14 \pm 0.83$ & $90.84 \pm 0.05$ \\
\hline Isoleucine & $90.57 \pm 0.66$ & $89.28 \pm 1.94$ & $90.62 \pm 0.95$ & $90.89 \pm 0.03$ \\
\hline Leucine & $91.71 \pm 0.15$ & $91.35 \pm 1.24$ & $91.62 \pm 0.83$ & $91.36 \pm 0.05$ \\
\hline Tyrosine & $91.87 \pm 0.80$ & $91.02 \pm 1.79$ & $91.52 \pm 1.60$ & $92.27 \pm 0.18$ \\
\hline Phenylalanine & $91.98 \pm 0.09$ & $92.42 \pm 1.28$ & $92.02 \pm 1.05$ & $92.28 \pm 0.21$ \\
\hline Lysine & $93.27 \pm 0.81$ & $92.46 \pm 1.00$ & $93.77 \pm 1.20$ & $93.94 \pm 0.07$ \\
\hline Arginine & $96.36 \pm 0.40$ & $95.98 \pm 0.50$ & $95.86 \pm 0.10$ & $95.91 \pm 0.12$ \\
\hline Methionine & $90.36 \pm 1.08$ & $90.98 \pm 3.11$ & $91.18 \pm 1.88$ & $92.03 \pm 0.35$ \\
\hline Total average & $91.98 \pm 0.57$ & $91.61 \pm 0.59$ & $92.19 \pm 0.46$ & $92.27 \pm 0.51$ \\
\hline
\end{tabular}

1) Originated from Argentina (ARG), India (IND), Korea (KOR) and U.S.A. (USA).

2) Values represent Mean \pm SE.

was $93.94 \%$ for USA, $93.77 \%$ for KOR, $93.27 \%$ for ARG and $92.46 \%$ for IND. The availability of methionine were $92.03 \%$ for USA, $91.18 \%$ for KOR, $90.98 \%$ for IND and $90.36 \%$ for ARG. The overall mean TAAA (92.0\%) were similar to the values reported by Lee and Garlich(1992) (90.37 92.16\%), Likuski and Dorrell (1978) (94\%), Green and Kiener (1989) (92\%). The overall means of lysine TAAA of SBM from USA and KOR tended to be higher than SBM from IND and ARG.

In vitro protein digestibilities of SBM from ARG, IND, KOR and USA are provided in Table 5. The values of UA ranged from $0.02(\mathrm{ARG})$ to $0.04(\mathrm{KOR}$, USA) but the differences were not significant. The values of $\mathrm{KOH}$ solubility were $84.15 \%$ for USA, $82.93 \%$ for IND, $82.04 \%$ for $\mathrm{KOR}$ and $73.49 \%$ for ARG. $\mathrm{KOH}$ solubility of SBM from ARG was significantly lower than SBM from other geographic origins $(\mathrm{p}<0.01)$. UA is widely applied to distinguish underprocessing of SBM (Kang and Chae, 2001), and the values lower than 0.2 were regarded as optimum processing condition for SBM(Vohra and Kratzer, 1991). On the contrary, $\mathrm{KOH}$ solubility is suitable to distinguish overprocessing of SBM(Araba and Dale, 1990), and proper

Table 5. In vitro assays to predict protein digestibility of soybean meals ${ }^{1), 2)}$

\begin{tabular}{lcccc}
\hline \multirow{2}{*}{ Items } & \multicolumn{4}{c}{ Soybean meals } \\
\cline { 2 - 5 } & ARG & IND & KOR & USA \\
\hline \hline Urease activity, $\mathrm{pH}$ unit & $0.02 \pm 0.01$ & $0.03 \pm 0.00$ & $0.04 \pm 0.02$ & $0.04 \pm 0.02$ \\
KOH solubility, \% protein & $73.49 \pm 0.52^{\mathrm{c}}$ & $82.93 \pm 0.39^{\mathrm{ab}}$ & $82.04 \pm 0.41^{\mathrm{b}}$ & $84.15 \pm 0.39^{\mathrm{a}}$ \\
\hline
\end{tabular}

\footnotetext{
1) Originated from Argentina (ARG), India (IND), Korea (KOR) and U.S.A. (USA).

2) Values represent Mean $\pm \mathrm{SE}$.

${ }^{\mathrm{a}-\mathrm{c}}$ values with different superscripts in a row were significantly differ $(\mathrm{P}<0.05)$.
} 
range of $\mathrm{KOH}$ solubility is known to be from $73 \%$ to $85 \%$ (Dale et al., 1987). Araba and Dale (1990) reported that there were no huge differences among the TAAA values of SBMs, if the $\mathrm{KOH}$ solubility values of SBMs were above $70 \%$. Although $\mathrm{KOH}$ solubility value of SBM from ARG was significantly lower than SBM from other geographic origins, the values of $\mathrm{KOH}$ solubility of all SBM used in this study were in the proper range. Therefore, SBMs from ARG, IND, KOR and USA were not underprocessed or overprocessed SBMs as shown by the values of UA and $\mathrm{KOH}$ solubility.

Dietary effects of SBM from ARG, IND, KOR and USA on body weight (BW), BW gain, feed intake and feed conversion rate (FCR) in broiler chicken are shown in Table 6. The average feed intake was similar among the treatments. The daily BW gain of USA group $(81.74 \mathrm{~g} / \mathrm{d})$ was the highest and that of IND $(77.45 \mathrm{~g} / \mathrm{d})$ was the lowest even though the differences among the treatments were not significant at 5\% level. The FCR in the chicks fed diet containing SBM from USA was significantly improved $(p<0.05)$ as compared to those of the other groups. The reason for the variation of performance may be associated with the differences in energy and amino acid availability. The experimental feed formula of this study used the contents of nutrients, not the values of bioavailability. An et al. (2007) reported that feed formulation based on bioavailability values, such as TMEn and TAAA, is an effective method for protecting the high variation in animal performance.

The dietary effects of SBM from ARG, IND, KOR and USA on carcass characteristics and serum profiles in broiler chicks are shown in Table 7 and 8, respectively. There were no significant differences in relative weight of liver, bursa of Febricius, abdominal fat, muscles of breast and leg among the treatments. The concentration of total cholesterol in serum did not vary significantly.

The results of in vitro assay and bioassay agreed with performance of broiler chicks, and thus there were close correlation among the broiler performance, and the measured nutritive values of SBM. In conclusion, dehulled SBM from USA was superior to non-dehulled SBM from ARG and IND with regard to nutritive value.

Table 6. Dietary effects of different origins of soybean meal on growth performances in broiler chicken ${ }^{1), 2)}$

\begin{tabular}{lcrrr}
\hline \multirow{2}{*}{ Items } & \multicolumn{4}{c}{ Soybean meals } \\
\cline { 2 - 5 } \multicolumn{1}{c}{ ARG } & \multicolumn{1}{c}{ IND } & KOR & USA \\
\hline \hline Initial BW, g/bird & $753.5 \pm 1.9$ & $755.1 \pm 0.2$ & $754.0 \pm 2.2$ & $754.2 \pm 1.3$ \\
Final BW, g/bird & $1,857.8 \pm 13.6$ & $1,839.4 \pm 12.4$ & $1,852.3 \pm 8.1$ & $1,898.6 \pm 25.7$ \\
BW gain, g/bird/day & $78.88 \pm 1.05$ & $77.45 \pm 0.89$ & $78.45 \pm 0.69$ & $81.74 \pm 1.76$ \\
Feed intake, g/bird/day & $137.94 \pm 1.63$ & $137.26 \pm 1.37$ & $136.84 \pm 1.45$ & $136.14 \pm 2.59$ \\
FCR, feed/gain & $1.75 \pm 0.01^{\mathrm{a}}$ & $1.77 \pm 0.01^{\mathrm{a}}$ & $1.74 \pm 0.01^{\mathrm{a}}$ & $1.67 \pm 0.01^{\mathrm{b}}$ \\
\hline
\end{tabular}

1) Originated from Argentina (ARG), India (IND), Korea (KOR) and U.S.A. (USA).

2) Values represent Mean $\pm \mathrm{SE}$.

${ }^{\mathrm{a}, \mathrm{b}}$ values with different superscripts in a row were significantly differ $(\mathrm{P}<0.05)$.

Table 7. Dietary effects of different origins of soybean meal on carcass characteristics in broiler chicken ${ }^{1), 2)}$

\begin{tabular}{|c|c|c|c|c|}
\hline \multirow{2}{*}{ Items } & \multicolumn{4}{|c|}{ Soybean meals } \\
\hline & ARG & IND & KOR & USA \\
\hline & \multicolumn{4}{|c|}{ 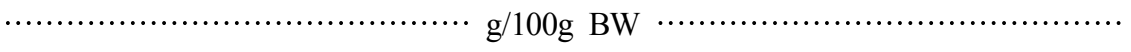 } \\
\hline Liver & $1.73 \pm 0.04$ & $1.76 \pm 0.03$ & $1.67 \pm 0.03$ & $1.77 \pm 0.06$ \\
\hline Bursa of Fabricius & $0.06 \pm 0.00$ & $0.05 \pm 0.00$ & $0.05 \pm 0.00$ & $0.05 \pm 0.01$ \\
\hline Abdominal fat & $2.09 \pm 0.11$ & $1.99 \pm 0.08$ & $1.83 \pm 0.08$ & $1.80 \pm 0.12$ \\
\hline Breast muscle & $9.36 \pm 0.16$ & $9.08 \pm 0.14$ & $9.32 \pm 0.23$ & $9.53 \pm 0.20$ \\
\hline Leg & $9.27 \pm 0.12$ & $9.51 \pm 0.10$ & $9.51 \pm 0.14$ & $9.30 \pm 0.14$ \\
\hline
\end{tabular}

1) Originated from Argentina (ARG), India (IND), Korea (KOR) and U.S.A. (USA).

2) Values represent Mean \pm SE. 
Table 8. Dietary effects of different origins of soybean meals on the concentration of serum cholesterol in broiler chicken $^{1,2), 3)}$

\begin{tabular}{ccccc}
\hline \multirow{2}{*}{ Items } & \multicolumn{4}{c}{ Soybean meals } \\
\cline { 2 - 5 } & ARG & IND & KOR & USA \\
\hline \hline \multirow{2}{*}{ Total-C, $\mathrm{mg} / \mathrm{dl}$} & $80.90 \pm 3.20$ & $78.94 \pm 2.39$ & $79.80 \pm 2.23$ & \multirow{2}{*}{$79.00 \pm 1.61$} \\
\hline
\end{tabular}

\footnotetext{
1) Originated from Argentina (ARG), India (IND), Korea (KOR) and U.S.A. (USA).

2) Abbreviation: Total-C, total cholesterol.

3) Values represent Mean $\pm \mathrm{SE}$.
}

\section{ABSTRACT}

This study was carried out to investigate the nutritional value of soybean meal (SBM) from various geographic origins and the effects of their dietary supplementation on performance of broiler chickens. Nutritional value of dehulled SBM originating from USA, and non-dehulled SBM from India (IND), Argentina (ARG) and Korea (KOR) were evaluated by analyzing chemical composition, urease activity (UA) and $\mathrm{KOH}$ solubility, and determining true metabolizable energy (TME), nitrogen corrected TME (TMEn) and true amino acid availability (TAAA). The contents of crude protein ranged from $45.43 \%$ (ARG) to $48.47 \%$ (USA) and those of crude fiber varied widely from $3.48 \%$ (USA) to $7.12 \%$ (IND). The measurements of lysine varied from $2.79 \%$ (IND) to $3.09 \%$ (USA) and those of methionine from $0.56 \%$ (IND) to $0.65 \%$ (USA). The values of TMEn varied from $2986.6 \mathrm{kcal} / \mathrm{kg}$ (IND) to $3228.9 \mathrm{kcal} / \mathrm{kg}$ (USA) and the averages of TAAA were from $91.61 \%$ (IND) to $92.27 \%$ (USA). UA was found to be from 0.02 (ARG) to 0.04 (KOR, USA) and those of $\mathrm{KOH}$ solubility from $73 \%$ (ARG) to $84 \%$ (USA). A total of four hundred 20-days-old male broiler chicks were divided into four groups and fed with isocaloric and isonitrogenous experimental diets containing $27.5 \%$ of SBM and same amounts of lysine and sulfur amino acids for 15 days. Final body weight and body weight gain were the highest in birds fed with SBM from USA and lowest in birds fed with SBM from IND although the differences were not statistically significant. The feed/gain in chicks fed diet containing SBM from USA was significantly improved $(p<0.05)$ compared to those of the other groups. There were no significant differences in carcass characteristics and the concentration of total cholesterol in serum among the treatments. The results of in vitro assay and bioassay agreed with the performance of broiler chicks, and thus there were close correlation between the broiler performance and the measured nutritive values of SBM. In conclusion, dehulled SBM from USA was superior to non- dehulled SBM from ARG and IND with regard to nutritive values.

\section{REFERENCES}

1. Aburto, A., Vazquez, M. and Dale, N. M. 1998. Strategies for utilizing overprocessed soybean meal:I. Amino acid supplementation, choline content, and metabolizable energy. J. Appl. Poult. Res. 7:189-195.

2. An, B. K., Im, H. J. and Kang, C. W. 2007. Nutritional values of red pepper seed oil meal and effects of its supplementation on performances and physiological responses of broiler chicks. Asian-Aust. J. Anim. Sci. 20:971-975.

3. Araba, M. and Dale, N. 1990. Evaluation of protein solubility as an indicator of overprocessing soybean meal. Poult. Sci. 69:76-83.

4. Association of Official Analytical Chemists, 2000. Official Methods of Analysis of the Association of Official Analytical Chemists, 17th ed.

5. Batal, A. B. and Parsons, C. M. 2003. Utilization of different soy products as affected by age in chicks. Poult. Sci. $82: 454-462$

6. Caskey, C. D. and Knapp, F. C. 1944. Method for detecting inadequately heated soybean oil meal. Ind. Eng. Chem. 16:641-642.

7. Dale, N. M., Araba, M. and Whittle, E. 1987. Protein solubility as an indicator of optimum processing of soybean meal. In : Proceedings Georgia Nutrition Conference, Athens, GA. pp 88-95.

8. Duncan, D. B. 1955. Multiple range and multiple $F$ test. Biometr., 11:1-42.

9. Eggum, B. O. and Beames, R. M. 1983. The nutritive value of seed proteins. In : Seed Proteins, Biochemistry, Genetics, Nutritive value. E. Gottschalk and H. P. Muller. pp 499-531.

10. Green, S. and Kiener, T. 1989. Digestibilities of nitrogen and amino acids in soya-bean, sunflower, meat and rapeseed meals 
measured with pigs and poultry. Anim. Prod. 48:157-179.

11. Joo, Y. J., Kang, K. R., Nham, K. T., Kang, C. W. and Jung, M. S. 1994. Evaluation of nutritional quality of soybean oil meals as poultry feedstuffs. Kor. J. Anim. Nutr. Feed. 18:340-345.

12. Kang, C. W. 1993. Quality and evaluation of feedstuffs. 5th Short-Course on Feed Technology, Korean Society of Animal Nutrition and Feeds. pp 334-350.

13. Kang, C. W. and Chae, B. J. 2001. A to Z on soybean meal American Soybean Association.

14. Lee, Heuisuck and Garlich, J. D. 1992. Effect of overcooked soybean meal on chicken performance and amino acid availability. Poult. Sci. 71:499-508.

15. Likuski, H. J. A. and Dorrell, H. G. 1978. A bioassay for rapid determinations of amino acid availability values. Poult. Sci. 57:1658-1660.

16. McNaughton, J. L., Reece, F. N. and Deaton, J. W. 1981. Relationships between color, trypsin inhibitor contents, and urease index of soybean meal and effects on broiler performance. Poult. Sci. 60:393-400.

17. NRC, 1994. Nutrient Requirements of Poultry, 9th ed. National Academy Press. Washington, D.C.

18. SAS Institute. 2002. SAS/STAT User's Guide : Statistics. Version 9.1, 4th Edition. SAS Institute Inc., Cary, NC.

19. Sibbald, I. R. 1979. A bioassay for amino acids and true metabolizable energy in feedingstuffs. Poult. Sci. 58:668-673.

20. Vohra, P. and Kratzer, F. H. 1991. Evaluation of soybean meal determines adequacy of heat treatment. Feedstuffs 63:22-28.

21. Whittle, E. and Araba, M. 1992. Sources of variability in the protein solubility assay for soybean meal. J. Appl. Poult. Res. 1:221-225.

22. Wright, K. N. 1981. Soybean meal processing and quality control. J. Am. Oil Chem. Soc. 19:294-303.

(접수일자 : 2009. 3. 9. / 수정일자 : 2009. 5. 25. /

채택일자 : 2009. 6. 8.) 